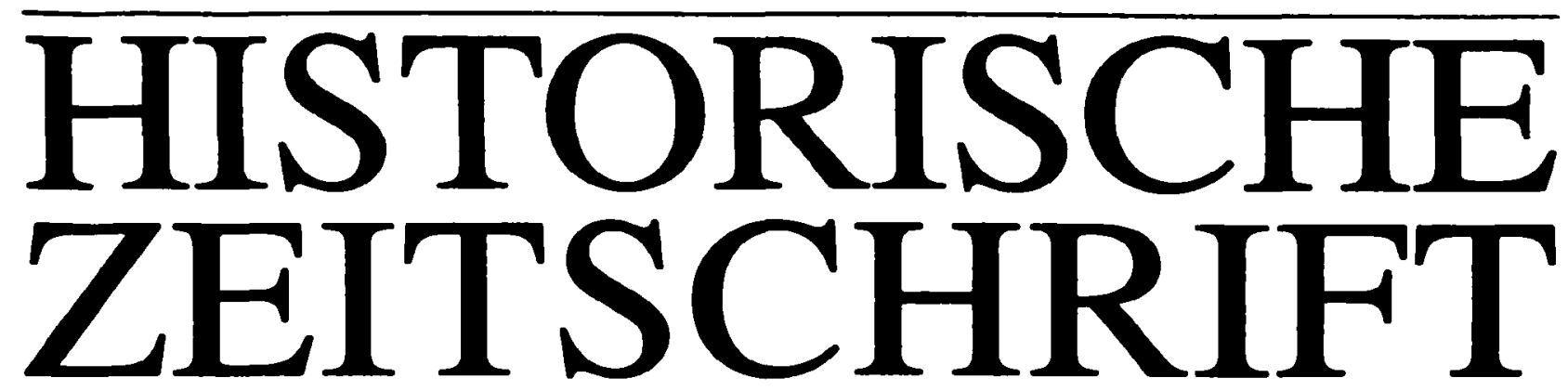

The extremely valuable source of information on European History.

The HISTORISCHE ZEITSCHRIFT began publication in 1859. This review, edited by Professor Lothar Gall, offers an outstanding forum for debate on German and international history. Its essays, its book reviews and its bibliographical notes provide a comprehensive picture of German and international history.

For all those concerned with history the HISTORISCHE ZEITSCHRIFT is a must.

The HISTORISCHE ZEITSCHRIFT is published six times a year, in February, April, June, August, October and December.

The annual subscription price 1992 (=6 issues, approx. 280 pages each) is DM 380,- plus postage.

Subscribers of HISTORISCHE ZEITSCHRIFT can obtain on special conditions the supplements ("Sonderhefte" and "Beihefte") and:

\title{
Historische Bibliographie
}

Edited by the "Arbeitsgemeinschaft außeruniversitärer historischer Forschungseinrichtungen in der Bundesrepublik Deutschland e.V.".

Last issue: Berichtsjahr 1989.

1990. 379 pages, special price for the subscribers of the HISTORISCHE ZEITSCHRIFT DM 68,-(instead of DM 88,-)

ISBN 3-486-64464-5

If you would like to know more about our journal, we will be pleased to send you the latest issue of HISTORISCHE ZEITSCHRIFT.

R. Oldenbourg Verlag

P.O.Box 8013 60, D-8000 München/West Germany

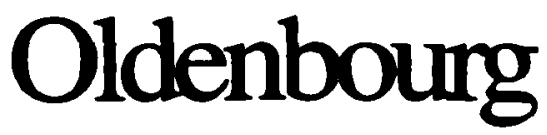




\section{CAMBRII)CiE}

The Worlds of Christopher Columbus

WILLIAM D. PHILLIPS and CARLA

RAHN PHILLIPS

Two leading researchers in early modern

Spanish history present an accurate and yet highly accessible account of the trials and achievements of Christopher

Columbus.

E16.95 net HB 0521350972336 pp.

Now in paperback

Geography, Technology and War

Studies in the Maritime History of the Mediterranean, 649-1571

JOHN H. PRYOR

'... a useful and scholarly book which

brings rogether an imposing mass of information ... this is a study which all interested in the medieval and early modern history of the Mediterranean will find of value.'

The Times Higher Education Supplement E13.95 net HB O 521428920256 pp. Past and Present Publications

Now in paperback

The Uses of Literacy in Early Medieval Europe Edited by ROSAMOND MCKITTERICK

Investigates the ways in which literacy was important in early medieval Europe, and examines the context of literacy, its uses, levels and distribution, in a number of different societies between $c .400$ and c. 1000 .

f14.95 net HB 0521428963368 pp.
Magna Carta

Second Edition

J. C. HOLT

'Holt treads this ground as a master and no-one can read his work without a deep respect for the care and accuracy with which he has assembled the details which give a fresh look to one of the most familiar stretches of English history.'

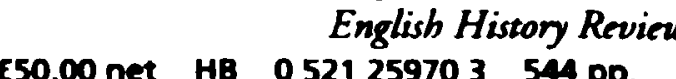
E15.95 net PB 0521277787

\section{Criminal Justice and Crime in Late Renaissance Florence, 1537-1609}

JOHN K. BRACKETT

Focusing on the court Otto Di Guardia e Balia, on its police, prisons and relations with other courts, John Brackett considers the nature and extent of princely power in Florence and reveals much about the rule of law in the capital city and its subject territory.

E24.95 net HB 0521404053192 pp.

\section{Virtue Transformed}

Political Argument in England, 1688-1740

SHELLEY BURTT

The book offers a detailed study of political argument in early eighteenthcentury England, a time in which the politics of virtue were vigorously pursued - and just as vigorously challenged. f30.00 net HB 0521375282256 pp. 


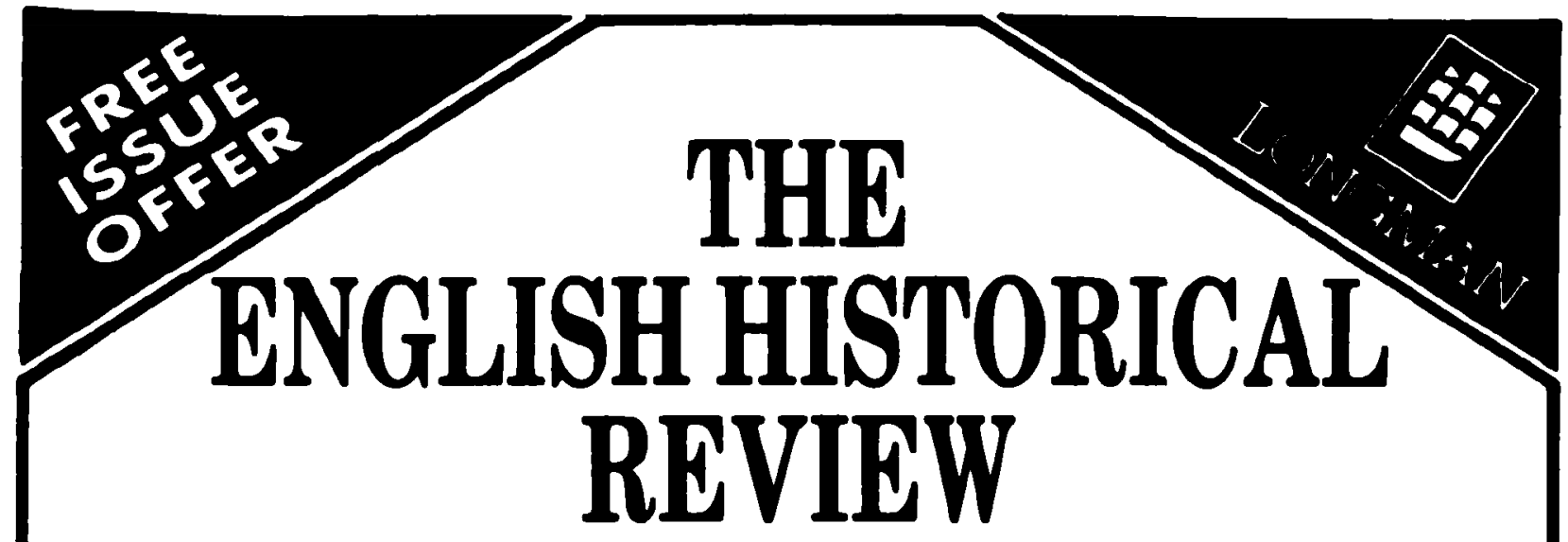

Edited by R.J.W. Evans and J.R. Maddicott

First published in 1886, The English Historical Review is the oldest quarterly journal of historical scholarship in the English-speaking world.

It deals with all aspects of European and world history, as well as the history of Britain itself, since the classical era.

The English Historical Review includes articles, 'Notes and Documents', and Debates on medieval and modern themes, as well as book reviews and a summary of international periodical literature.

\section{FREE SAMPLE ISSUE...}

Why not look at the journal with no obligation? To obtain a FREE recent issue, simply complete the coupon below and return to:

Judy Higgins, LHE, Longman House, Burnt Mill, Harlow, Essex CM20 2JE, UK.

$\begin{array}{lccc}1992 \text { Subscription } & \text { UK } & \text { Overseas } & \text { N.America } \\ \text { Vol } 107 \text { (4 issues) } & £ 56.00 & £ 62.00 & \$ 105.00\end{array}$

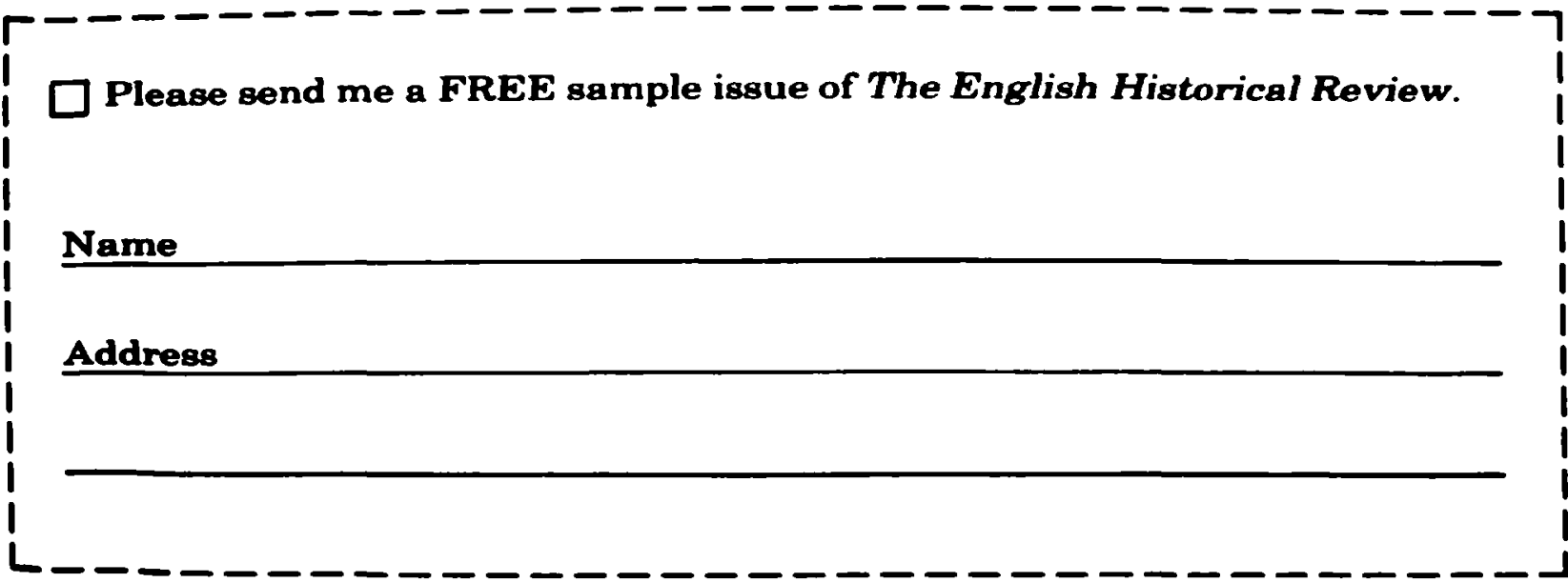




\section{REVUE FRANÇAISE D'HISTOIRE D'OUTRE-MER explorations, colonisations, indépendances}

Editee per

ChuRLES-ROBert AGERON. Universite Paris XII

Volume 78

n. 292

Richard B. ALLEN : Lives of meisher luxury nor misery : Indians and Free colored marginality on the lle de France (1728-1810).

A. Felix IRoro : Les hammes d'offaires français et le commerce des cauris du $X V I I^{e}$ an $X X^{e}$ sidcle.

Bernard Giule : L'Assemblé LLgislative tahitienre (1824-1880).

Serge DAOET : La traile des Noirs par l'Allantique depuis 1988.

COMPTES RENDUS.

\section{n. 293}

H.J.K. JenreINs : Guadeloupe, Martinique and commerce raiding : two colonies in conflict, 1797-1798.

Hubert BONm : Le Comptoir national d'escomple de Paris, une banque imperiale (1848-1940).

Pascal VENIER : Lyamey et l'idle de protectorat de 1894 d 1902 : Gendse d'ure doctrine coloniale.

Antoine J. BuLLIER : Powvoir culturel et politique d'apartheid (1930-1980).

Jean-Pietre MoreaU : Un nouveau úmoignage sur la a rencontre des Deux Mondes , dans les Petites Antilles.

COMPTES RENDUS

Prix du numito : 90 FF

Conditions d'abonnement (4 numeros par an)

France: 280 FF Etranger: 325 FF supplement avion 60 FF

SOCIETE FRANÇAISE D'HISTOIRE D'OUTRE-MER

9 ne Robert-de-Flers, 75015 Paris. FRANCE 
1 All contributions. correspondence, and books for review should be sent to: The Editors, The Heverical Gournal. Faculty of History. West Road. Cambridge CB'3 QFF.

2 The Historical Journal publistes articles on all aspeces of history since the fifteenth contury.

3 Artides must mot evered 10,000 words and communications 5.000 nords in length.

+ Contributions should be typed double-spaced on Af paper. with fexemotes eyped separately at the end of the contribution. and must observe the tepographical and stylistic conventions of the Journal. A style-sheet is avaliable from the Editors on request.

5 Authors should submit the top (oppy of their typescript and kecp another copy to assist in their correction of proofs.

6 Submission of an article is taken wimply that it has not previously been published, and is not being considered for publication elsewhere. Authors are also asked to provide brief details of any related article or boxk they are publishing elsewhere.

7 Authors who wish their contributions to be returned if not accepted for publication are asked co enclose return pestage or international pestage coupons. 


\section{THE \\ H IS TOR I C A L \\ JOURNAL}

VOLUME 35,2 JUNE $199^{2}$

\section{CONTENTS}

\section{A R TICLES}

Stecen (;. Ellis A border baron and the Tudor state: the rise and fall of Lord Dacre of the North

Markku Peltonen Politics and science: Francis Bacon and the true greatness of states

Joyce Lee .Malcolm Charles II and the reconstruction of royal power

J. $R$. Oldfield The London Committee and mobilization of public opinion against the slave trade

I. J. Riall Liberal policy and the control of public order in western Sicily a $860 \quad$ I 862

.Michael Dau'son Money and the real impact of the Fourth Reform Act

Alfred-Maurice de Zavas 'The Wehrmacht bureau on war crimes

Harold L. Smith The politics of Conservative reform: the equal pay

HISTORIOGRAPHIC:AL REVIEW

REVIEW ARTICLES

OTHER REVIEWS

See page i for full list of contents

(C) Cambridge University Press 1992 